\title{
Transintestinal transport mechanisms of 5-aminosalicylic acid (in situ rat intestine perfusion, Caco- 2 cells) and Biopharmaceutics Classification System
}

\author{
Libuše Smetanová, Věra Štětinová, Dagmar Kholová, Martin Kuneš, Milan Nobilis, Zbyněk \\ Svoboda and Jaroslav Květina
}

Institute of Experimental Biopharmaceutics, Joint Research Centre of the Academy of Sciences of the Czech Republic and PRO.MED.CS Praha a.s., Hradec Králové, Czech Republic

\begin{abstract}
The aim of the study was 1) to estimate permeability of 5-aminosalicylic acid (5-ASA),2) to categorize 5-ASA according to BCS (Biopharmaceutics Classification System), and 3) to contribute to determination of 5-ASA transintestinal transport and biotransformation mechanisms.

The in situ rat intestine perfusion was used as an initial method to study 5-ASA transport. The amount of 5-ASA (released from tablet) transferred into portal circulation reached $5.79 \pm 0.24 \%$. During this transport, the intestinal formation of 5-ASA main metabolite ( $N$-ac-5-ASA) occurred. $\mathrm{N}$-ac-5-ASA was found in perfusate both from intestinal lumen and from v. portae.

In in vitro Caco-2 monolayers, transport of 5-ASA $(10-1000 \mu \mathrm{mol} / \mathrm{l})$ was studied in apical-basolateral and basolateral-apical direction (iso-pH 7.4 conditions). The transport of total 5-ASA (parent drug plus intracellularly formed $N$-ac-5-ASA) was linear with time, concentration- and direction-dependent. Higher basolateral-apical (secretory) transport was mainly caused by higher transport of the metabolite (suggesting metabolite efflux transport). Transport of 5-ASA (only parent drug) was saturable (transepithelial carrier-mediated) at low doses, dominated by passive, paracellular process in higher doses which was confirmed by increased 5-ASA transport using $\mathrm{Ca}^{2+}$-free transport medium. The estimated low 5-ASA permeability and its low solubility enable to classify 5-ASA as BCS class IV.
\end{abstract}

Key words: 5-ASA - Transintestinal transport - In situ rat intestine perfusion - Caco-2 cells - Biopharmaceutics Classification System (BCS)

Abbreviations: 5-ASA, 5-aminosalicylic acid; AP, apical; BCS, Biopharmaceutics Classification System; BL, basolateral; Caco-2, human colon carcinoma cell line; HBSS, Hanks' balanced salt solution (transport medium); HPLC, high performance liquid chromatography; MRP, multidrug resistance-associated proteins; $N$-ac-5-ASA, $N$-acetyl-5-aminosalicylic acid; OATP, organic anion transporting polypeptide; $\mathrm{P}_{\mathrm{app}}$, apparent permeability coefficient; P-gp, P-glycoprotein; $\mathrm{R}^{2}$, coefficient of determination.

\section{Introduction}

Amidon et al. (1995) revealed that the fundamental parameters controlling the rate and extent of oral drug absorption are the permeability of the drug through the gastrointestinal

Correspondence to: Libuše Smetanová, Institute of Experimental Biopharmaceutics, Joint Research Centre of the Academy of Sciences of the Czech Republic and PRO.MED.CS Praha a.s., Heyrovského 1207, Hradec Králové 500 03, Czech Republic E-mail: liba.smetanova@seznam.cz membrane and the solubility of the drug and devised Biopharmaceutics Classification System (BCS) that categorized drugs into four classes according to their solubility and permeability. Drug classes are defined as: Class 1: High solubility-high permeability drugs; Class 2: Low solubility-high permeability drugs; Class 3: High solubility-low permeability drugs; Class 4: Low solubility-low permeability drugs. The objective of the BCS is to predict in vivo pharmacokinetic performance of drug products from measurements of permeability and solubility. The BCS has provided a simple and facile scientific framework for drug development and 
in connection with dissolution may help decisions to obtain regulatory waivers for bioequivalence studies for oral drug formulations.

The models commonly used to determine drug permeability are, among others, in vitro model of the Caco- 2 cell monolayer and the in situ model of rat intestinal perfusion (Kim et al. 2006). No study categorizing 5-aminosalicylic acid (5-ASA; mesalazine), drug commonly prescribed in the treatment of inflammatory bowel diseases (Prakash and Markham 1999; Bergman and Parkes 2006), into the BCS has been published so far. Oral 5-ASA preparations are generally formulated to release the drug in the terminal ileum and colon, where it is thought to exert its effects via topical actions (De Vos et al. 1992; Clemett and Markham 2000). The absorbed portion of 5-ASA is almost completely acetylated in the gut wall and in the liver to its major metabolite $N$-acetyl-5-aminosalicylic acid ( $N$-ac-5-ASA) (Zhou et al. 1999; Hu and Peppercorn 2008). N-ac-5-ASA does not have an anti-inflammatory effect.

The in vitro experiments with transport of 5-ASA across Caco-2 monolayers have so far provided contradictory results. In the study of Zhou et al. (1999) some evidence was provided for carrier-mediated transepithelial transport at low concentrations of 5-ASA $(65.4 \mu \mathrm{mol} / \mathrm{l})$, which was saturable at higher levels $(\geq 654 \mu \mathrm{mol} / \mathrm{l})$. In the study of Liang et al. (2000), 5-ASA $(100 \mu \mathrm{mol} / \mathrm{l})$ was not a substrate of efflux pumps. And also Xin et al. (2006) concluded in their study that the intestinal secretion of 5-ASA observed in vivo is unlikely to be mediated by the efflux transporters P-glycoprotein (P-gp) or multidrug resistance-associated protein 2 (MRP2). The involvement of organic anion transporting polypeptide (OATP) family in the transport mechanism of 5-ASA was suggested by König et al. (2011).

The initial experiments utilized an in situ single-pass rat intestine perfusion method i) to study 5-ASA transport processes in the intestine and ii) to clarify whether metabolic conversion of 5-ASA to its metabolite ( $N$-ac-5-ASA) occurs in the intestinal wall. The aim of Caco-2 experiments was 1) to estimate the permeability of 5-ASA, 2) to categorize 5-ASA into one of the BCS classes, and 3) to contribute to the determination of 5-ASA transintestinal transport mechanisms.

\section{Materials and Methods}

\section{Rat intestine in situ single-pass perfusion}

Male Wistar Han II rats weighing $265 \pm 38 \mathrm{~g}$ were used in the study. The experiment was approved by the Institutional Review Board of Animal Care Committee of Institute of Experimental Biopharmaceutics, the Czech Academy of Sciences.
The modified perfusion method (Pang et al. 1986; Doherty and Pang 2000; Cong et al. 2001; Kuneš et al. 2005a) was used in this initial study. A perfuser, composed of two reservoir units and two peristaltic pumps (S 31 Domet), was used for single-pass perfusion of rat small intestine. Krebs-Henseleit (K-H) solution was the perfusate (reservoir 1 ) flowing into the mesenterial bed. Phosphate buffer solution ( $\mathrm{pH}$ 7.4) from reservoir 2 flows continuously into the lumen of small intestine. A thermostable plexiglass box (where the rat was placed) was used to maintain the temperature of the process at $37^{\circ} \mathrm{C}$. K-H solution used as medium for mesenterial system perfusion was prepared before each experiment. It was prepared by mixing the distilled water, the basic solution and $\mathrm{NaHCO}_{3}$ in proportion 4.2/1.05/1. The basic solution was mixed with $\mathrm{NaCl}, \mathrm{KCl}, \mathrm{CaCl}_{2}, \mathrm{KH}_{2} \mathrm{PO}_{4}, \mathrm{MgSO}_{4} .7 \mathrm{H}_{2} \mathrm{O}$ (all from Fluka). Final concentration of salts in $100 \mathrm{ml}$ of $\mathrm{K}-\mathrm{H}$ solution was: $\mathrm{NaCl} 706.8 \mathrm{mg}, \mathrm{KCl} 43.6 \mathrm{mg}, \mathrm{CaCl}_{2} 2.8 \mathrm{mg}, \mathrm{KH}_{2} \mathrm{PO}_{4} 16.5 \mathrm{mg}$, $\mathrm{MgSO}_{4} .7 \mathrm{H}_{2} \mathrm{O} 2.9 \mathrm{mg}$. Polyvinylpyrrolidone K25 (Fluka) has been added to $\mathrm{K}-\mathrm{H}$ solution to colloidal balancing. This solution was gassed with $95 \% \mathrm{O}_{2}: 5 \% \mathrm{CO}_{2}$ and adjusted to pH 7.4 using 0.1 M HCl. Phosphate buffer solution (0.067 M) adjusted to $\mathrm{pH} 7.4$ was the perfusate coming into the luminal part of small intestine.

Surgery was done in general anaesthesia (intraperitoneal dose of urethane, $1.5 \mathrm{~g} / \mathrm{kg}$, Sigma Aldrich). After laparotomy, superior mesenteric artery (inflow) and portal vein (outflow) were cannulated. The perfusion process using the perfusate from reservoir $1(2.5 \mathrm{ml} / \mathrm{min})$ was initiated immediately after the cannulation. Subsequently, duodenum was incised $3 \mathrm{~cm}$ below the stomach for administration of tablet core containing 5-ASA (100 mg mesalazine substance; prepared in the laboratory of PRO.MED.CS Praha a.s., Czech Republic). Before tablet core administration, the intestine had been subjected to a single flush by the blank phosphate buffer $(40 \mathrm{ml}$; temperated to $37^{\circ} \mathrm{C}$ ). After that, the cannula was fixed in the duodenal incision to introduce the perfusate under constant flow $0.4 \mathrm{ml} / \mathrm{min}$ from reservoir 2 . For analysis, samples were withdrawn at $5,10,20,30,45,60,75$ and 90 min from ileum and portal vein. The concentrations of 5-ASA and its metabolite $N$-ac-5-ASA in perfusate samples were detected by HPLC (Nobilis et al. 2006).

\section{Caco-2 cell experiments}

Caco-2 cells (from the European Collection of Cell Culture (ECACC), Sigma-Aldrich, Czech Republic) were cultured in a standard manner (Bourdet and Thakker 2006; Stetinova et al. 2009) in plastic tissue culture flasks (TPP AG, Switzerland) in Dulbecco's modified Eagle's medium with high glucose (PAA Laboratories (BioTech, Czech Republic)) at $37^{\circ} \mathrm{C}$ in atmosphere of $5 \% \mathrm{CO}_{2}$ and $90 \%$ relative humidity. For 5-ASA transport studies, Caco- 2 cells (passages 79-85) were seeded onto the Transwell inserts (TPP AG, Switzerland) at a density 
of $2.5 \times 10^{5}$ cells $/ \mathrm{cm}^{2}$ and grown to late confluence (22-24 days). Medium was changed three times a week and daily during the last 3-5 days ( $500 \mu \mathrm{l}$ to the insert compartment - the apical side, and $650 \mu \mathrm{l}$ to the well compartment - the basolateral side). Caco-2 cells were grown for at least 21 days to allow formation physiologically and morphologically (polarization, differentiation) well developed confluent cell monolayers prior to initiating drug transport studies (Hidalgo et al. 1989; Vachon and Beaulieu 1992; Walle and Walle 1998).

\section{Cell viability assay}

Cell viability was determined by Trypan blue exclusion method (Lu et al. 2005; Smetanova et al. 2009). Caco-2 cells were seeded onto Petri dishes (area $9.2 \mathrm{~cm}^{2}$ ) at a density of 2 $\times 10^{5} \mathrm{cells} / \mathrm{cm}^{2}$ and cultured for $24 \mathrm{~h} .5$-ASA $(1000 \mu \mathrm{mol} / \mathrm{l})$ or transport medium (as a control) was then added and incubated for $2 \mathrm{~h}$. Then the cells were released from the dishes and incubated with $0.4 \%$ Trypan blue for $5 \mathrm{~min}$ and counted by using light microscopy.

\section{Monolayer integrity assessment}

Before the start of the experiment, the monolayer integrity was checked by $500 \mu \mathrm{mol} / \mathrm{l}$ phenol red permeability/ $1 \mathrm{~h}$ (Fleet and Wood 1999; Garcia-Casal et al. 2000; Smetanova et al. 2008) measured by spectrophotometry at $558 \mathrm{~nm}$ (Spekol 11). During transport studies, Caco-2 cell monolayer integrity was confirmed simultaneously by measuring ${ }^{14} \mathrm{C}$-mannitol permeability (Artursson et al. 1996; Baird and Prosser 1998). ${ }^{14} \mathrm{C}$ mannitol $(0.5 \mu \mathrm{Ci} / \mathrm{ml}$; Moravek Radiochemical and Biochemicals (MGP Zlín, Czech Republic)) transport was examined in apical to basolateral direction for $2 \mathrm{~h}$ and samples were counted using liquid scintillation analyser (Beckman LS 5000TD).

\section{Transport studies}

Transport experiments with 5-ASA (Sigma-Aldrich, Czech Republic) were performed as previously described (Walle and Walle 1998; Stetinova et al. 2009; Smetanova et al. 2009). Briefly, the inserts were rinsed twice and equilibrated with prewarm Hanks' balanced salt solution (HBSS; PAA Laboratories (BioTech, Czech Republic)) at $37^{\circ} \mathrm{C}$ for $30 \mathrm{~min}$ before the transport studies. The AP-BL (apical-to-basolateral) transport experiments were initiated by replacing the transport medium with the diluted 5-ASA $(10,100,300$, and $1000 \mu \mathrm{mol} / \mathrm{l})$ in the transport medium on the apical side. The samples $(500 \mu \mathrm{l})$ from the basolateral compartment were withdrawn at 30, 60, 90 and $120 \mathrm{~min}$ for HPLC analysis (determination of 5-ASA and metabolite $N$-ac-5-ASA). Similarly, for basolateral-to-api$\mathrm{cal}$ (BL-AP) transport, the drug was added to the basolateral compartment and samples $(300 \mu \mathrm{l})$ from the apical compart- ment withdrawn in the same time intervals. To determine paracellular component of the 5-ASA $(300 \mu \mathrm{mol} / \mathrm{l})$ transport, the HBSS $\mathrm{Ca}^{2+}$-free medium was used (for washes, $30 \mathrm{~min}$ preincubation and for the transport study).

Apparent permeability coefficient $\mathrm{P}_{\text {app }}(\mathrm{cm} / \mathrm{s})$ was calculated (Artursson and Karlsson 1991):

$$
\mathrm{P}_{\mathrm{app}}=(\mathrm{dQ} / \mathrm{d} t) \times\left(1 /\left(\mathrm{A} \times \mathrm{C}_{0}\right)\right)
$$

where $\mathrm{d} Q / \mathrm{d} t$ is the permeability rate, the amount of drug appearing in the receiver compartment in function of time $(\mathrm{nmol} / \mathrm{s}), \mathrm{C}_{0}$ is the initial concentration in the donor chamber $(\mathrm{nmol} / \mathrm{ml})$, and $\mathrm{A}$ is the surface area of the monolayer $\left(\mathrm{cm}^{2}\right)$. Transport in both directions across monolayer enables to calculate (Ungell and Karlsson 2004):

$$
\mathrm{P}_{\mathrm{app}} \text { efflux ratio }=\mathrm{P}_{\mathrm{app}}(\mathrm{BL}-\mathrm{AP}) / \mathrm{P}_{\mathrm{app}}(\mathrm{AP}-\mathrm{BL})
$$

The flux rate $\left(\mathrm{nmol} / \mathrm{min} / \mathrm{cm}^{2}\right)$ of the 5 -ASA was determined from the slope of the plot of the cumulatively transported amount versus time using linear regression analysis and the flux rates were plotted versus 5-ASA concentrations.

All used solutions and transport media were sterile filtered just before the experiments. All experiments were carried out under sink conditions so that the concentrations of the drug in the receiver compartment would not exceed $10 \%$ of applicated dose in the donor side.

\section{HPLC analysis of 5-ASA and N-ac-5-ASA}

The quantification of 5-ASA was performed by high performance liquid chromatography (HPLC) with gradient elution. A modified method of Nobilis et al. (2006) was used. Withdrawn samples in transport medium were analyzed for 5-ASA and $N$-ac-5-ASA. Chromatographic separation was performed on the analytical column LichroCART ${ }^{\circ}$ (250 $\times 4 \mathrm{~mm})$ packed with Purospher RP-18e $(5 \mu \mathrm{m})$ and precolumn LiChroCART ${ }^{\circledast} 4-4$ with the same stationary phase (Merck, Darmstadt, Germany). The mobile phase A consisted of acetonitrile-UHQ water $(8: 2, \mathrm{v} / \mathrm{v})$, the mobile phase $\mathrm{B}$ contained acetonitrile- $0.01 \mathrm{M} \mathrm{Na} \mathrm{HPO}_{4}$ buffer $(\mathrm{pH} 3)$ in the ratio 15:85 (v/v). The flow-rate was $1 \mathrm{ml} / \mathrm{min}$ and elution of 5-ASA and $N$-ac-5-ASA was monitored at the fluorescence excitation wavelength of $300 \mathrm{~nm}$ and emission wavelength of $406 \mathrm{~nm}$, the total run was $21 \mathrm{~min}$ for each sample. The quantitative determination was based upon the integration of fluorescence peak area.

\section{Statistical analysis}

All values are represented as mean \pm standard deviation (SD). Statistical differences were determined using Kruskal-Wallis 
one way analysis of variance (ANOVA) with Scheffe's post test. The differences were considered significant when $p<0.05$. All treatments were carried out at least in triplicate $(n=3-4)$.

\section{Results}

\section{Rat intestine in situ single-pass perfusion}

After intraduodenal administration of tablets containing 5ASA (100 mg), the amount of substance that reached the portal circulation during a 90-minute intestinal perfusion was $5.79 \pm$ $0.24 \%$. The major metabolite of 5-ASA, i.e. $N$-ac-5-ASA, was detectable both in the intestinal perfusate (the luminal concentration of the metabolite reached $0.36 \%$ of parent drug 5-ASA), and in the portal circulation $(0.07 \pm 0.11 \%)$ (Fig. 1).

\section{Caco-2 cell experiments}

\section{Cell viability}

5-aminosalicylic acid (5-ASA) in concentration of $1000 \mu \mathrm{mol} / \mathrm{l}$ did not influence Caco-2 cell viability in comparison with viability of Caco-2 cells incubated with transport medium (98.0 $\pm 0.7 \%$ vs. $98.6 \pm 0.5 \%$, not significant).

\section{The monolayer integrity assessment}

The $\mathrm{P}_{\text {app }}$ value of phenol red $/ 1 \mathrm{~h}$ was $0.64 \pm 0.22 \times 10^{-6} \mathrm{~cm} / \mathrm{s}$ and percent cumulative transport reached $0.18 \pm 0.06 \%$.

The $\mathrm{P}_{\mathrm{app}}$ of mannitol after $2 \mathrm{~h}$ was $1.93 \pm 0.10 \times 10^{-6}$ $\mathrm{cm} / \mathrm{s}$ (Fig. 2) and corresponded to the percent cumulative transport $1.46 \pm 0.01 \%$. There was no effect of 5 -ASA in concentration of $300 \mu \mathrm{mol} / \mathrm{l}$ on the $\mathrm{P}_{\mathrm{app}}$ of ${ }^{14} \mathrm{C}$ mannitol $\left(2.02 \pm 0.01 \times 10^{-6} \mathrm{~cm} / \mathrm{s}\right.$; Fig. 2).

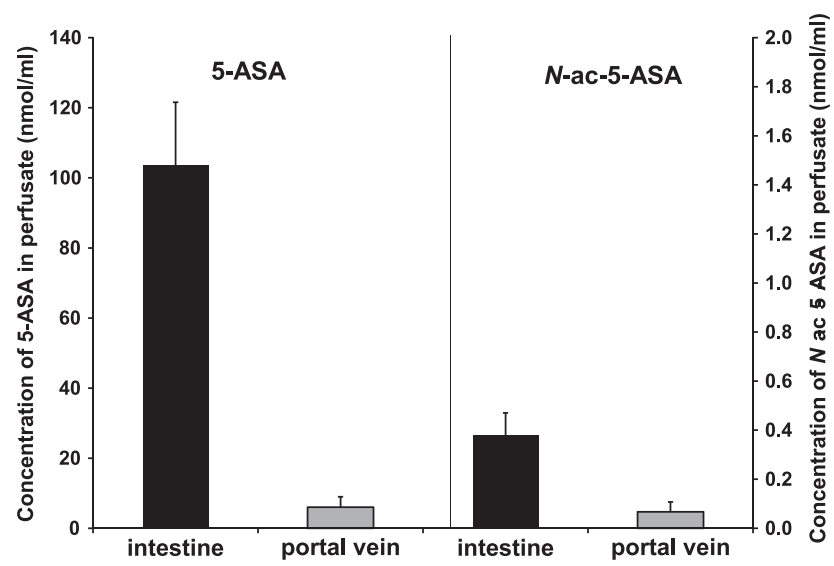

Figure 1. Concentration of 5-ASA and $\mathrm{N}$-ac-5-ASA in perfusion samples. Results represent the mean $\pm \mathrm{SD}$.

\section{Transport studies of total 5-ASA (sum of 5-ASA and intracellularly formed $N$-ac-5-ASA)}

\section{The cumulative transport of total 5-ASA}

The cumulative transport of total 5-ASA (nmol; Fig. 3) was linear for up to $120 \mathrm{~min}$ over the concentration range examined for both directions (AP-BL and BL-AP) with the exception of the AP-BL transport in the dose of $1000 \mu \mathrm{mol} / 1$ where the transport was linear only up to $90 \mathrm{~min}$. The BLAP transport was higher than AP-BL in the concentrations of 300 and $1000 \mu \mathrm{mol} / \mathrm{l}$ and was almost the same in the concentrations of 10 and $100 \mu \mathrm{mol} / \mathrm{l}$.

\section{The permeability values $\left(P_{a p p}\right)$ and efflux ratios of 5-ASA}

The permeability values ( $\mathrm{P}_{\mathrm{app}}$ ) of 5-ASA (Fig. 4) were higher in the BL-AP than in AP-BL direction in all used concentrations but the difference in the transport (AP-BL vs. BL-AP) was statistically significant only in the dose of $10 \mu \mathrm{mol} / \mathrm{l}$ (2.87 vs. $\left.4.97 \times 10^{-6} \mathrm{~cm} / \mathrm{s}\right)$. In the dose of 100,300 and $1000 \mu \mathrm{mol} / \mathrm{l}$ the $\mathrm{P}_{\text {app }}$ values were $1.20-0.66 \times 10^{-6} \mathrm{~cm} / \mathrm{s}$ for AP-BL transport and $1.32-1.04 \times 10^{-6} \mathrm{~cm} / \mathrm{s}$ in BL-AP direction, $\mathrm{P}_{\text {app }}$ values decreased with the increased dose of 5-ASA. The $\mathrm{P}_{\text {app }}$ values were significantly lower in the doses 100, 300 and $1000 \mu \mathrm{mol} / \mathrm{l}$ in comparison with the permeability of 5-ASA in the dose of $10 \mu \mathrm{mol} / \mathrm{l}$ both in AP-BL and BL-AP direction. The $\mathrm{P}_{\mathrm{app}}$ efflux ratio (Fig. 4) was almost the same

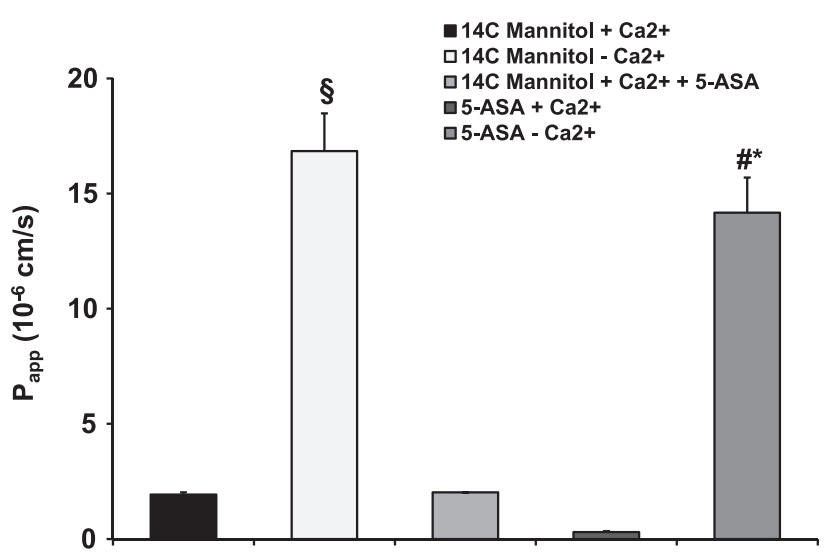

Figure 2. The effect of the presence $\left(+\mathrm{Ca}^{2+}\right)$ or absence $\left(-\mathrm{Ca}^{2+}\right.$; opening tight junctions) of $\mathrm{Ca}^{2+}$ in the transport medium on the apical-basolateral (AP-BL) transport of 5-ASA $(300 \mu \mathrm{mol} / \mathrm{l})$ and of ${ }^{14} \mathrm{C}$ mannitol (paracellular marker). Transport of 5-ASA was estimated as transport of parent drug (5-ASA) plus intracellularly formed metabolite $(\mathrm{N}$-ac-5-ASA $)$. The effect of 5-ASA on the monolayer integrity $\left({ }^{14} \mathrm{C}\right.$ mannitol $+\mathrm{Ca}^{2+}+5$-ASA). Each column represents the mean $\pm \mathrm{SD}$ of permeability coefficient $\left(\mathrm{P}_{\mathrm{app}}\right) . \S p<0.05$ vs. ${ }^{14} \mathrm{C}$-mannitol $+\mathrm{Ca}^{2+}$, ${ }^{*} p<0.05$ vs. ${ }^{14} \mathrm{C}-$ mannitol $-\mathrm{Ca}^{2+}$, $\# p<0.05$ vs. 5-ASA $+\mathrm{Ca}^{2+}$. 


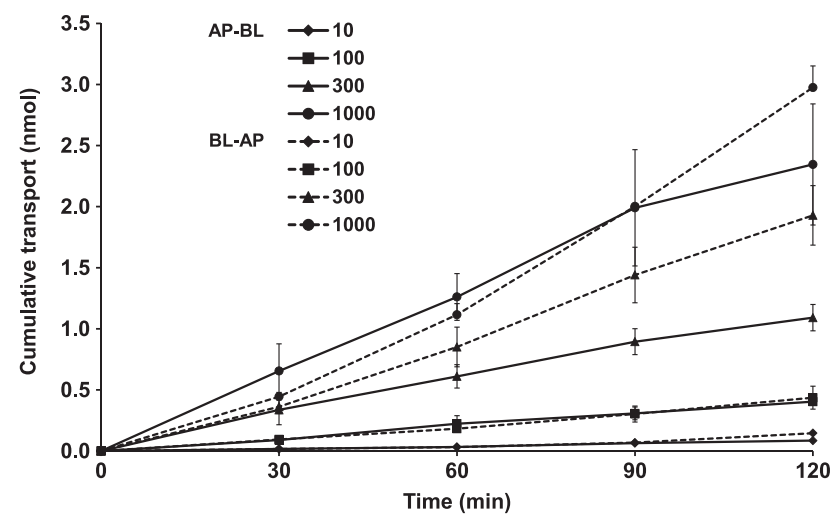

Figure 3. The cumulative transport of 5-ASA $(10-1000 \mu \mathrm{mol} / \mathrm{l})$ in the apical-basolateral direction (AP-BL, solid line) and basolateral-apical (BL-AP, dashed line) estimated as transport of parent drug (5-ASA) plus intracellularly formed metabolite ( $\mathrm{N}$-ac-5-ASA) under iso-pH $(\mathrm{pH}$ 7.4/7.4) conditions. Results are expressed as mean \pm SD.

for the doses 10, 300 and $1000 \mu \mathrm{mol} / \mathrm{l}$ (around 1.7) and was the lowest in the dose of $100 \mu \mathrm{mol} / \mathrm{l}$ (1.2).

The transport of the ${ }^{14} \mathrm{C}$-mannitol (paracellular marker) and also the transport of 5-ASA (AP-BL; $300 \mu \mathrm{mol} / \mathrm{l}$ ) was significantly enhanced (8.73-times and 46.8-times) by the use of the HBSS $\mathrm{Ca}^{2+}$-free transport medium in comparison with using transport medium with $\mathrm{Ca}^{2+}$. There was statistical difference between $\mathrm{P}_{\mathrm{app}}$ of 5-ASA and $\mathrm{P}_{\text {app }}$ of ${ }^{14} \mathrm{C}$-mannitol with the HBSS $\mathrm{Ca}^{2+}$-free transport medium (Fig. 2).

\section{The AP-BL and BL-AP flux rates}

The AP-BL flux rate was lower than $\mathrm{BL}-\mathrm{AP}$ flux rate; flux rates were not a simple linear function of 5-ASA concentrations

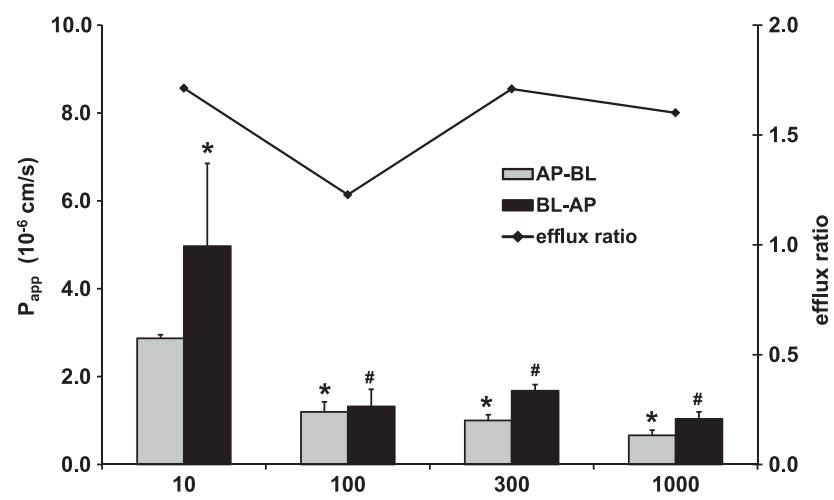

Figure 4. The 5-ASA $(10-1000 \mu \mathrm{mol} / \mathrm{l})$ permeability and the efflux ratios. Each column represents the mean \pm SD of permeability coefficient $\left(\mathrm{P}_{\text {app }}\right)$. Efflux ratio $=\mathrm{P}_{\text {app }} \mathrm{BL}-\mathrm{AP} / \mathrm{P}_{\text {app }}$ AP-BL. ${ }^{*} p<0.05$ vs. $10 \mu \mathrm{mol} / \mathrm{l} \mathrm{AP}-\mathrm{BL}, \# p<0.05$ vs. $10 \mu \mathrm{mol} / \mathrm{l} \mathrm{BL}-\mathrm{AP}$.

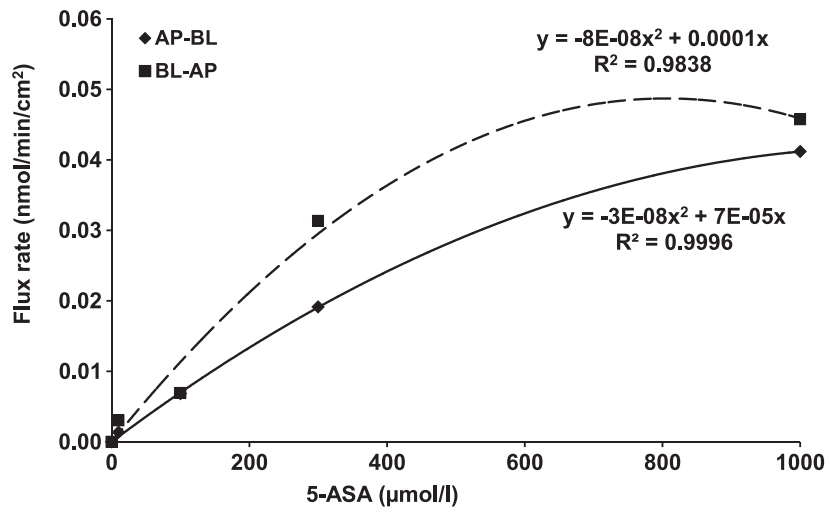

Figure 5. Comparison of AP-BL (apical-basolateral) and BLAP (basolateral-apical) transport of 5-ASA across Caco-2 monolayers. The flux rates $(\mathrm{J})$ were determined in the time course (0-120 min) of AP-BL or BL-AP transport at various concentrations.

but polynomic function of the concentrations, indicating saturability of the 5-ASA transport (Fig. 5).

\section{Transport studies of 5-ASA and intracellularly formed $N$-ac-5-ASA (separately)}

The percent cumulative transport of the parent drug 5-ASA and its metabolite ( $N$-ac-5-ASA), separately, in both directions (AP-BL and BL-AP) is shown in Fig. 6 (only $120 \mathrm{~min}$ interval).

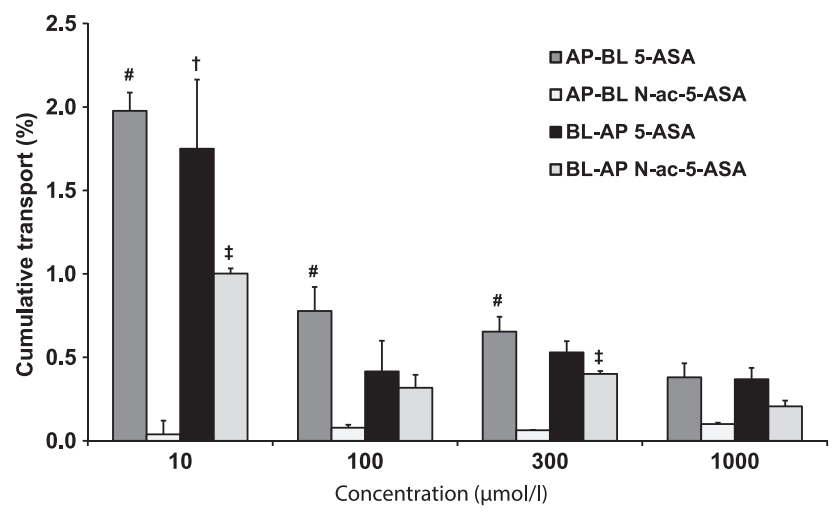

Figure 6. The percent transport of 5-ASA and intracellularly formed metabolite $\mathrm{N}$-ac-5-ASA, separately, in 120 min interval. AP-BL (apical-basolateral), BL-AP (basolateral-apical) transport. Each column represents the mean $\pm \mathrm{SD}$. ${ }^{*} p<0.05$, 5-ASA AP-BL vs. 5-ASA BL-AP (not significant); \# $p<0.05$, 5 -ASA AP-BL $v s$. $N$-ac-5-ASA AP-BL; $\dagger p<0.05$, 5-ASA BLAP vs. $N$-ac-5-ASA BL-AP; $\neq p<0.05, N$-ac-5-ASA AP-BL $v s$. $N$-ac-5-ASA BL-AP. 


\section{The transport of 5-ASA}

The transport of 5-ASA was higher in AP-BL vs. BL-AP direction in all used doses (10-1000 $\mu \mathrm{mol} / \mathrm{l}$; non significantly) and was the highest in the dose of $10 \mu \mathrm{mol} / \mathrm{l}$ (about $2 \%$ ); with increasing the dose, the transport decreased to about $0.38 \%$ in the highest used dose $(1000 \mu \mathrm{mol} / \mathrm{l})$.

\section{The transport of $\mathrm{N}-a c-5-\mathrm{ASA}$}

The transport of $\mathrm{N}$-ac-5-ASA was higher in BL-AP direction vs. AP-BL direction $(0.21-1.00 \%$ vs. $0.04-0.10 \%)$ with statistical significance in the dose of 10 and $300 \mu \mathrm{mol} / \mathrm{l}$. The transport of metabolite in the BL-AP direction was the highest in the dose of $10 \mu \mathrm{mol} / \mathrm{l}(1.00 \%)$ and the lowest in the dose of $1000 \mu \mathrm{mol} / \mathrm{l}(0.21 \%)$.

There was statistical difference in the BL-AP transport of metabolite in the dose of $10 \mu \mathrm{mol} / \mathrm{l} v \mathrm{~s}$. BL-AP transports of metabolite in other doses $(100,300$ and $1000 \mu \mathrm{mol} / \mathrm{l})$, but there was no statistical difference among BL-AP transports of metabolite in doses 100, 300 and $1000 \mu \mathrm{mol} / \mathrm{l}$. There was no statistical difference among the AP-BL transports of metabolite in all used doses.

\section{Comparison of the transport of 5-ASA and N-ac-5-ASA}

The percent cumulative transport of 5-ASA (parent drug) was higher than transport of the metabolite $N$-ac-5-ASA in the AP-BL direction significantly in the doses $10-300 \mu \mathrm{mol} / 1$ and non significantly in the dose of $1000 \mu \mathrm{mol} / \mathrm{l}$. Also in the BL-AP direction the cumulative transport of 5-ASA (parent drug) was higher than transport of the metabolite $N$-ac-5ASA but significantly only in the dose of $10 \mu \mathrm{mol} / \mathrm{l}$.

\section{The appearance of $\mathrm{N}$-ac-5-ASA in the donor and receiver compartment}

The appearance of the intracellularly formed metabolite $(\mathrm{N}$ ac-5-ASA) in the donor and receiver compartment at the end of the experiment (120 min) after administration of 5-ASA in the concentration range $(10-1000 \mu \mathrm{mol} / \mathrm{l})$ to the donor compartment is shown in Table 1.

\section{The study of AP-BL transport of 5-ASA}

In the study of AP-BL transport of 5-ASA (administration of 5-ASA to the apical (donor) compartment), higher concentrations of $\mathrm{N}$-ac-5-ASA were seen in the donor compartment in comparison with the receiver (basolateral) compartment in the concentrations of $100-1000 \mu \mathrm{mol} / \mathrm{l}$. In the dose of $10 \mu \mathrm{mol} / \mathrm{l}$, the metabolite could have been determined neither in the donor nor in the receiver compartment.

\section{The study of BL-AP transport of 5-ASA}

In the study of BL-AP transport of 5-ASA (administration of 5-ASA to the basolateral (donor) compartment), higher concentrations of $\mathrm{N}$-ac-5-ASA were also seen in the donor compartment (similarly as in the AP-BL transport) in comparison with the receiver (apical) compartment in the concentrations of $10-1000 \mu \mathrm{mol} / \mathrm{l}$ with one exception: in the dose of $300 \mu \mathrm{mol} / \mathrm{l}$ the concentration of the metabolite was higher in the receiver compartment.

\section{Comparison of AP-BL vs. BL-AP transports of 5-ASA}

Comparing the AP-BL and BL-AP transports (donor and receiver compartments, respectively), the concentrations of the metabolite were higher in the donor compartments in AP-BL $v s$. BL-AP directions (with exception of $10 \mu \mathrm{mol} / \mathrm{l}$ ) and in the receiver compartments in the BL-AP direction in comparison with AP-BL transports.

\section{Discussion}

As regards the initial study (rat in situ model), the singlepass perfusion technique was utilized i) on the basis of our

Table 1. The appearance of intracellularly formed metabolite of 5-ASA ( $N$-ac-5-ASA) in the donor and receiver compartment at the end of the AP-BL and BL-AP transport (120 min) after administration of 5-ASA (10-1000 $\mu \mathrm{mol} / \mathrm{l})$ to the donor compartment, respectively

\begin{tabular}{|c|c|c|c|c|}
\hline \multirow{3}{*}{$\begin{array}{l}N \text {-ac-5-ASA } \\
(\mu \mathrm{mol} / \mathrm{l})\end{array}$} & \multicolumn{4}{|c|}{ Transport of 5-ASA } \\
\hline & \multicolumn{2}{|c|}{ AP-BL } & \multicolumn{2}{|c|}{ BL-AP } \\
\hline & $\mathrm{D}(\mathrm{AP})$ & $\mathrm{R}(\mathrm{BL})$ & $\mathrm{D}(\mathrm{BL})$ & $\mathrm{R}(\mathrm{AP})$ \\
\hline 10 & $0.00 \pm 0.00$ & $0.00 \pm 0.01$ & $0.13 \pm 0.04$ & $0.11 \pm 0.08$ \\
\hline 100 & $1.44 \pm 0.12$ & $0.06 \pm 0.00$ & $0.81 \pm 0.26$ & $0.37 \pm 0.02$ \\
\hline 300 & $1.88 \pm 0.44$ & $0.15 \pm 0.01$ & $0.18 \pm 0.32$ & $1.66 \pm 0.11$ \\
\hline 1000 & $4.57 \pm 0.31$ & $0.58 \pm 0.06$ & $3.26 \pm 0.43$ & $2.14 \pm 0.14$ \\
\hline
\end{tabular}

Data are expressed as mean \pm SD. AP, apical; BL, basolateral; D, donor compartment; R, receiver compartment. 
experience of studying of various transport mechanisms in the rat intestine (Kuneš et al. 2005a, 2005b) and ii) on the basis of comparably similar literature data (Schurgers et al. 1986; Fagerholm et al. 1996). This in situ method was primarily targeted for eventual confirmation of the biotransformation formation of 5-ASA metabolite ( $N$-ac-5-ASA) selectively in the intestinal wall (excluding extraintestinal pharmacokinetic compartments, such as liver). The conversion of 5-ASA to $\mathrm{N}$-acetyl metabolite was dose-dependent in the sense of parent drug concentration. In addition to this confirmation, the presence of $\mathrm{N}$-ac-5-ASA in the perfusate that had passed through intestinal lumen was an interesting observation. This could indicate a possible exsorption of metabolite (depending on the concentration gradient) into the intestinal content. Based on these results subsequent studies of the metabolic activity on the Caco-2 monolayer model were carried out.

The first aim of the Caco-2 experiments was to estimate 5-ASA permeability and to categorize 5-ASA into one of the BCS classes on the basis of 5-ASA permeability and solubility. The values of 5-ASA $\mathrm{P}_{\mathrm{app}} \mathrm{s}$ around $1 \times 10^{-6} \mathrm{~cm} / \mathrm{s}(100-1000$ $\mu \mathrm{mol} / \mathrm{l})$ indicate low-permeability drug. The solubility of 5-ASA was found to be $9.37 \pm 0.02 \mathrm{mg} / \mathrm{ml}$ water at $\mathrm{pH} 7.4$ (Tuğcu-Demiröz et al. 2004). As for this solubility, 5-ASA is slightly soluble according to the semiquantitative range for solubility (Lipinski 2004). According to low permeability and low solubility, 5-ASA should be classified as class IV of the BCS.

The second objective of the Caco-2 studies was to contribute to the determination of 5-ASA transepithelial transport mechanisms as in vitro experiments with transport of 5-ASA across Caco-2 monolayers have provided contradictory results so far. The cumulative transport of total 5-ASA (parent drug plus intracellularly formed $\mathrm{N}$ acetyl metabolite) was linear with time in both directions and was concentration- and direction-dependent (BL-AP > $\mathrm{AP}-\mathrm{BL})$ in all concentrations $(10-1000 \mu \mathrm{mol} / \mathrm{l})$. Flux rates (J) indicated saturability of 5-ASA transport. The percent transport of total 5-ASA was the highest in the dose of 10 $\mu \mathrm{mol} / 1$ ( $>2 \%$ in both directions) with higher BL-AP than AP-BL transport (data not shown). In the other doses, the percent transport was about $0.5-1 \%$. Also Zhou et al. (1999) showed the difference in the percent transport in the low vs. higher doses, $10-20 \%$ vs. $2-5 \%$, respectively. To the contrary Xin et al. (2006) reported the percent concentration-independent transport of 5-ASA. Analysis of the percent transport of parent drug (5-ASA) and its metabolite ( $N$-ac-5-ASA), separately, was done. The real transport of parent drug was higher in the AP-BL vs. BL-AP direction and was concentration-dependent (the highest in the dose of $10 \mu \mathrm{mol} / \mathrm{l})$. It was in the contrary to higher BL-AP transport of total 5-ASA transport (as a sum of transport of parent drug plus metabolite). This was caused by considerably higher transport of $N$-ac-5-ASA in the $\mathrm{BL}-\mathrm{AP}$ vs. AP-BL direction. This implies involvement of efflux transporter in the transport of metabolite from the cell to the apical chamber. As reported Yoshimura et al. (2009), $N$-ac-5-ASA was discharged 5.3, 7.1, and 8.1-fold higher into the apical than into the basolateral site during 1,2 , and 4-hour incubations, respectively, after apical administration of 5-ASA $(200 \mu \mathrm{mol} / \mathrm{l})$ in Caco- 2 cells. They also demonstrated that the apical efflux of $N$-ac-5-ASA is suppressed by inhibition of MRPs ' pumps located on apical membranes in Caco- 2 cells. Also in our AP-BL transport study, $\mathrm{N}$-ac-5-ASA was discharged in higher extent to the apical than to the basolateral compartment. This can imply saturation of the apical efflux or saturation of the metabolite formation.

Obtained efflux ratios (about 1.7) are, however, boundary for definition of active efflux involvement (Yazdanian et al. 2004; Yu and Zeng 2007). Analogous value of efflux ratios of 5 -ASA $(100 \mu \mathrm{mol} / \mathrm{l})$ were reported by Liang et al. (2000) who claimed that 5-ASA is not a substrate of efflux transporters. And also Xin et al. (2006) concluded that the intestinal secretion of 5-ASA observed in vivo is unlikely to be mediated by the efflux transporters P-gp or MRP2. However, in an agreement with Yoshimura et al. (2009) as mentioned above, our experiments suggested efflux of $\mathrm{N}$-ac-5-ASA which could be the molecular mechanism of secretion of $\mathrm{N}$-ac-5-ASA into the gut lumen. Clinical studies also indicated that this metabolite is secreted back from the enterocytes into the gut lumen (Goebell et al. 1993; Layer et al. 1995).

Detail analysis of the percent transport of 5-ASA alone vs. $N$-ac-5-ASA that the transport of 5-ASA alone is lowering with increasing dose. In the dose of 10 and $100 \mu \mathrm{mol} / \mathrm{l}$ AP-BL percent transport was higher ( $v s$. BL-AP), which might suggest a carrier-mediated transepithelial transport of the proper 5-ASA. König et al. (2011) demonstrated that intracellular accumulation of 5-ASA $(20 \mu \mathrm{mol} / \mathrm{l})$ is mediated by members of the OATP uptake transporter family. Domination of the passive transport in the higher doses is probable as the percent transport of the proper 5-ASA was almost the same in AP-BL and BL-AP direction. With regard to physicochemical properties of 5-ASA, more probable is the passive transepithelial transport of 5-ASA via paracellular pathway than via lipid membrane permeation (Zhou et al. 1999). To confirm the paracellular component of the 5-ASA transport in the Caco- 2 cells, we used the $\mathrm{Ca}^{2+}$-free transport medium for opening the tight junctions (Delie and Rubas 1997; Ungell and Karlsson 2004; McMillan et al. 2005). When this $\mathrm{Ca}^{2+}$-free medium was used, the $\mathrm{P}_{\text {app }}$ of ${ }^{14} \mathrm{C}$ mannitol (positive control for the paracellular pathway) was significantly increased and also the $\mathrm{P}_{\mathrm{app}}$ of 5-ASA $(300 \mu \mathrm{mol} / \mathrm{l})$ was significantly enhanced giving an evidence for the paracellular component involved in the 5-ASA transport. 


\section{Conclusion}

The initial study (rat in situ model) showed the maximal rate of absorption of released 5-ASA during the first $60 \mathrm{~min}$ (under given experimental conditions). During perfusion, 5-ASA was transported across the intestinal wall. And simultaneously during this transport, 5-ASA was converted into the 5-ASA metabolite ( $N$-ac-5-ASA).

The estimated low 5-ASA permeability and its low solubility enable to classify 5-ASA as class IV of the BCS. The transport of the total 5-ASA (parent drug plus intracellularly formed $\mathrm{N}$-acetyl metabolite) was linear with time, concentration- and direction-dependent. Higher BL-AP (secretory) transport was mainly caused by higher transport of the metabolite (suggesting efflux transport of the metabolite). The transport of proper 5-ASA (parent drug) was saturable (transepithelial carrier-mediated) at low doses, dominated by passive, paracellular process in higher doses which was confirmed by increased 5-ASA transport using $\mathrm{Ca}^{2+}$-free transport medium. Thus, the 5-ASA transport is a coordination of several processes which go in the same or in the opposite direction depending on the concentration of 5-ASA and are further complicated by the intracellular metabolite production and by the metabolite transport.

Acknowledgements. The study was supported by the research project GAČR 305/08/0535. The authors wish to thank Mrs. Hana Machová for her skilful technical assistance.

\section{References}

Amidon G. J., Lennernäs H., Shap V. P., Crison J. R. (1995): A theoretical basis for a biopharmaceutic drug classification: the correlation of in vitro drug product dissolution and in vivo bioavailability. Pharm. Res. 12, 413-420 http://dx.doi.org/10.1023/A:1016212804288

Artursson P., Karlsson J. (1991): Correlation between oral drug absorption in humans and apparent drug permeability coefficients in human intestinal epithelial (Caco-2) cells. Biochem. Biophys. Res. Comm. 175, 880-885 http://dx.doi.org/10.1016/0006-291X(91)91647-U

Artursson P., Karlsson J., Ocklind G., Schipper N. (1996): Studying transport process in absorptive epithelia. In: Epithelial Cell Culture - a Practical Approach. (Ed. A. J. Shaw), pp. 11-133, Oxford University Press

Baird A. W., Prosser E. S. (1998): Cell culture models for polarized epithelial monolayers. In: Animal Cell Culture Techniques. (Ed. M. Clynes), pp. 298-318, Springer-Verlag Berlin, Heidelberg, New York http://dx.doi.org/10.1007/978-3-642-80412-0_17

Bergman R., Parkes M. (2006): Systematic review: the use of mesalazine in inflammatory bowel disease. Aliment Pharmacol. Ther. 23, 841-855 http://dx.doi.org/10.1111/j.1365-2036.2006.02846.x
Bourdet D. L., Thakker D. R. (2006): Saturable absorptive transport of the hydrophilic organic cation ranitidine in Caco-2 cells: role of $\mathrm{pH}$-dependent organic cation uptake system and Pglycoprotein. Pharm. Res. 23, 1165-1177 http://dx.doi.org/10.1007/s11095-006-0251-4

Clemett D., Markham A. (2000): Prolonged-release mesalazine: a review of its therapeutic potential in ulcerative colitis and Crohn's disease. Drugs 59, 929-956 http://dx.doi.org/10.2165/00003495-200059040-00016

Cong D., Fong A. K. Y., Lee R., Pang K. S. (2001): Absorption of benzoic acid in segmental regions of the vascularly perfused rat small intestine preparation. Drug Metab. Dispos. 29, 1539-1547

Delie F., Rubas W. (1997): A human colonic cell line sharing similarities with enterocytes as a model to examine oral absorption: advantages and limitations of the Caco-2 model. Crit. Rew. Ther. Drug Carrier Syst. 14, 221-286 http://dx.doi.org/10.1615/CritRevTherDrugCarrierSyst.v14. i3.20

De Vos M., Verdievel H., Schoonjans R., Praet M., Bogaert M., Barbier F. (1992): Concentrations of 5-ASA and Ac-5-ASA in human ileocolonic biopsy homogenates after oral 5-ASA preparations. Gut 33, 1338-1342 http://dx.doi.org/10.1136/gut.33.10.1338

Doherty M. M., Pang K. S. (2000): Route-dependent metabolism of morphine in the vascularly perfused rat small intestine preparation. Pharm. Res. 17, 291-298 http://dx.doi.org/10.1023/A:1007548905772

Fagerholm U., Johansson M., Lennernas H. (1996) : Comparison between permeability coefficients in rat and human jejunum. Pharm. Res. 13, 1336-1342 http://dx.doi.org/10.1023/A:1016065715308

Fleet J. C., Wood R. J. (1999): Specific 1,25(OH)2D3-mediated regulation of transcellular calcium transport in Caco-2 cells. Am. J. Physiol. Gastrointest. Liver Physiol. 276, G958-964

Garcia-Casal M. N., Leets I., Layrisse M. (2000): $\beta$-Carotene and inhibitors of iron absorption modify iron uptake by Caco- 2 cells. J. Nutr. 130, 5-9

Goebell H, Klotz U, Nehlsen B, Layer P. (1993): Oroileal transit of slow release 5-aminosalicylic acid. Gut 34, 669-675 http://dx.doi.org/10.1136/gut.34.5.669

Hidalgo I. J., Raub T. J., Borchardt R. T. (1989): Characterization of the human colon carcinoma cell line (Caco-2) as a model system for intestinal epithelial permeability. Gastroenterology 96, 736-749

Hu M. Y., Peppercorn M. A. (2008): MMX mesalamine: a novel high-dose, once-daily 5-aminosalicylate formulation for the treatment of ulcerative colitis. Expert Opin. Pharmacother. 9, 1049-1058 http://dx.doi.org/10.1517/14656566.9.6.1049

Kim J. S., Mitchell S., Kijek P., Tsume Y., Hilfinger J., Amidon G. L. (2006): The suitability of an in situ perfusion model for permeability determinations: utility for BCS class I biowaiver requests. Mol. Pharm. 3, 686-694 http://dx.doi.org/10.1021/mp060042f

König J., Glaeser H., Keiser M., Mandery K., Klotz U., Fromm M. F. (2011): Role of organic anion-transporting polypeptides for cellular mesalazine (5-aminosalicylic acid) uptake. Drug Metab. Dispos. 39, 1097-1102 
http://dx.doi.org/10.1124/dmd.110.034991

Kuneš M., Květina J., Svoboda Z., Herout V. (2005a): Study of the mechanisms of intestinal absorption of xenobiotics using in situ perfusion of rat intestine. Biologia 60 (Suppl. 17), 89-92

Kuneš M., Svoboda Z., Květina J., Herout V., Herink J., Bajgar J. (2005b): Intestinal single-pass in situ perfusion technique in rat: The influence of L-carnitine on absorption of 7-methoxytacrine. Biomed. Pap. Med. Fac. Univ. Palacky Olomouc Czech Repub. 149, 433-435 http://dx.doi.org/10.5507/bp.2005.075

Layer P. H., Goebell H., Keller J., Dignass A., Klotz U. (1995): Delivery and fate of oral mesalamine microgranules within the human small intestine. Gastroenterology 108, 1427-1433 http://dx.doi.org/10.1016/0016-5085(95)90691-6

Liang E., Proudfoot J., Yazdanian M. (2000): Mechanisms of transport and structure-permeability relationship of sulfasalazine and its analogs in Caco-2 cell monolayers. Pharm. Res. 17, $1168-1174$ http://dx.doi.org/10.1023/A:1026450326712

Lipinski Ch. (2004): Aqueous solubility in discovery, chemistry, and assay changes. In: Drug Bioavailability. (Eds. H. Waterbeemd, H. Lennernäs and P. Artursson), pp. 215-231, 2nd reprint, Wiley-Vch. Verlag GmbH\&Co. KGaA, Weinheim

Lu Y., Heydel J. M., Li X., Bratton S., Lindblom T., RadominskaPandya A. (2005): Lithocholic acid decreases expression of UGT2B7 in Caco-2 cells: a potential role for a negative farnesoid X receptor response element. Drug Metab. Dispos. 33, 937-946 http://dx.doi.org/10.1124/dmd.104.003061

McMillan J. M., Walle U. K., Walle T. (2005): S-adenosyl-L-methionine: transcellular transport and uptake by Caco- 2 cells and hepatocytes. J. Pharm. Pharmacol. 57, 599-605 http://dx.doi.org/10.1211/0022357056082

Nobilis M., Vybiralova Z., Sladkova K., Lisa M., Holcapek M., Kvetina J. (2006): High-performance liquid-chromatographic determination of 5-aminosalicylic acid and its metabolites in blood plasma. J. Chromatogr. A. 1119, 299-308 http://dx.doi.org/10.1016/j.chroma.2006.01.058

Pang K. S., Yuen V., Fayz S., Te Koppele J. M., Mulder G. J. (1986): Absorption and metabolism of acetaminophen by the in situ perfused rat small intestine. Drug Metab. Dispos. 14, 102-111

Prakash A., Markham A. (1999): Oral delayed-release mesalazine: a review of its use in ulcerative colitis and Crohn's disease. Drugs 57, 383-408 http://dx.doi.org/10.2165/00003495-199957030-00013

Schurgers N., Bijdendijk J., Tukker J. J., Crommelin D. J. A. (1986) : Comparison of four experimental techniques for studying drug absorption kinetics in the anesthetized rat in situ. J. Pharm. Sci. 75, 117-119 http://dx.doi.org/10.1002/jps.2600750203
Smetanova L., Stetinova V., Kvetina J., Svoboda Z. (2008): The use of 14C- mannitol and phenol red in the assessment of the Caco-2 monolayer integrity. Prague Medical Report 109 (Suppl.), S109-111

Smetanova L., Stetinova V., Kholova D., Kvetina J., Smetana J., Svoboda Z. (2009): Caco-2 cells and Biopharmaceutics classification system (BCS) for prediction of transepithelial transport of xenobiotics (model drug: caffeine). Neuroendocrinol. Lett. 30 (Suppl. 1), 101-105

Stetinova V., Smetanova L., Kholova D., Svoboda Z., Kvetina J. (2009): Transepithelial transport of ambroxol hydrochloride across human intestinal Caco-2 cell monolayers. Gen. Physiol. Biophys. 28, 309-315 http://dx.doi.org/10.4149/gpb_2009_03_309

Tuğcu-Demiröz F., Acartürk F., Takka S., Konuş-Boyunağa O. (2004): In-vitro and in-vivo evaluation of mesalazine-guar gum matrix tablets for colonic drug delivery. J. Drug Target. 12, 105-112 http://dx.doi.org/10.1080/10611860410001693751

Ungell A-L., Karlsson J. (2004): Cell culture in drug discovery: an industrial perspective. In: Drug Bioavailability. (Eds. H. Waterbeemd, H. Lennernäs and P. Artursson), pp. 90-131, 2nd reprint, Wiley-Vch. Verlag GmbH\&Co. KGaA, Weinheim

Vachon P. H., Beaulieu J.-F. (1992): Transient mosaic patterns of morphological and functional differentiation in the Caco- 2 cell line. Gastroenterology 103, 414-423

Walle U. K., Walle T. (1998): Taxol transport by human intestinal epithelial Caco-2 cells. Drug Metab. Dispos. 26, 343-346

Xin H. W., Schwab M., Klotz U. (2006): Transport studies with 5aminosalicylate. Eur. J. Clin. Pharmacol. 62, 871-875 http://dx.doi.org/10.1007/s00228-006-0182-3

Yazdanian M., Briggs K., Jankovsky C., Hawi A. (2004): The „high solubility" definition of the current FDA Guidance on Biopharmaceutical Classification System may be too strict for acidic drugs. Pharm. Res. 21, 293-299 http://dx.doi.org/10.1023/B:PHAM.0000016242.48642.71

Yoshimura S., Kawano K., Matsumura R., Sugihara N., Furuno K. (2009): Inhibitory effect of flavonoids on the efflux of $\mathrm{N}$-acetyl 5-aminosalicylic acid intracellularly formed in Caco-2 cells. J. Biomed. Biotechnol. 2009, 467-489 http://dx.doi.org/10.1155/2009/467489

Yu L., Zeng S. (2007): Transport characteristics of zolmitriptan in a human intestinal epithelial cell line Caco-2. J. Pharm. Pharmacol. 59, 655-660 http://dx.doi.org/10.1211/jpp.59.5.0005

Zhou S. Y., Fleisher D., Pao L. H., Li C., Winward B., Zimmermann E. M. (1999): Intestinal metabolism and transport of 5-aminosalicylate. Drug Metab. Dispos. 27, 479-485

Received: September 9, 2012

Final version accepted: February 11, 2013 